\title{
RAGAM GENOTIPE IKAN TENGADAK, Barbonymus schwanenfeldii (Bleeker 1854) PERSILANGAN POPULASI JAWA DAN KALIMANTAN BERDASARKAN RAPD
}

\author{
Deni Radona**\#, Dinar Tri Soelistyowati**), Rudhy Gustiano*), Odang Carman**), \\ Irin Iriana Kusmini*), dan Sri Sundari*) \\ *) Balai Penelitian dan Pengembangan Budidaya Air Tawar \\ ** Departemen Budidaya Perairan, FPIK-Institut Pertanian Bogor
}

\begin{abstract}
ABSTRAK
Dalam rangka pengelolaan sumber genetik untuk pengembangan budidaya ikan tengadak maka perlu dilakukan evaluasi sumber genetik ikan tengadak asal Jawa dan Kalimantan, serta progeni hibridanya. Analisis genetik dilakukan secara molekuler dengan metode RAPD. Jumlah sampel yang digunakan untuk analisis RAPD sebanyak 10 ekor setiap populasi. Spesimen yang digunakan untuk analisis RAPD adalah sirip untuk induk dan whole body untuk hibrida. Hasil menunjukkan polimorfisme $(32,43 \%$ dan heterozigositas $(0,13)$ tertinggi terdapat pada ikan tengadak hasil persilangan betina Jawa x jantan Kalimantan, sedangkan yang terendah diperoleh pada persilangan betina Kalimantan $\mathrm{x}$ jantan Jawa (polimorfisme: $21,62 \%$ dan heterozigositas: 0,10 ). Berdasarkan dendrogram hubungan kekerabatan interpopulasi ikan tengadak hasil persilangan (betina Kalimantan $\mathrm{x}$ jantan Jawa) dengan induknya (populasi Jawa dan Kalimantan) menggunakan tiga primer RAPD (OPA-08, OPA-09, dan OPC-02) menunjukkan jarak genetik berkisar 0,48. Ikan tengadak betina asal Jawa dan jantan asal Kalimantan potensial meningkatkan keragaman genetik.
\end{abstract}

\section{KATA KUNCl: RAPD; heterozigositas; ikan tengadak; polimorfisme}

ABSTRACT: Genetic diversity of outbreed tinfoil barb from Java and Kalimantan based on RAPD. By: Deni Radona, Dinar Tri Soelistyowati, Rudhy Gustiano, Odang Carman, Irin Iriana Kusmini, and Sri Sundari

\begin{abstract}
In order to maintain the genetic sources of tinfoil barb for aquaculture development, it is necessary to evaluate the genetic diversity crossbred results of tinfoil barb from Java and Kalimantan. The genetic assessment was conducted by genotype trails using RAPD methods. The samples used for the analysis of RAPD was as much as 10 individuals. Specimens used for RAPD analysis was a fin for broodstock and whole body for the hybrid fish. The result showed that the highest polymorphism and heterozygosity were found $32.43 \%$ and 0.13 in population crossbred of female Java $x$ male Kalimantan. While the lowest polymorphism and heterozygosity were detected on population of $f$ Kalimantan $x$ mJava (21.62\%and 0.10 , respectively). Based on the relationship between tinfoil barb hybrid (female Kalimantan $x$ male Java) with a both broodstock population using three RAPD primers (OPA-08, OPA-09, and OPC-02) resulted in genetic distance of 0.48 . Females tinfoil barb from Kalimantan and males from Java potential could increase genetic diversity.
\end{abstract}

\section{KEYWORDS: RAPD; heterozygosity; tinfoil barb; polymorphism}

\section{PENDAHULUAN}

Keragaman genetik merupakan hierarki yang paling rendah dalam tingkatan keragaman hayati yang menggambarkan keragaman fenotipe di dalam spesies yang merefleksikan keragaman sampai pada level DNA. Ikan tengadak Barbonymus schwanenfeldii (Bleeker,

\footnotetext{
\# Korespondensi: Balai Penelitian dan Pengembangan Budidaya Air Tawar. Jl. Sempur No. 1, Bogor 16151, Indonesia. Tel.: + (0251) 8313200

E-mail: deniradona_kkp@yahoo.com
}

1854) merupakan ikan lokal asli perairan tawar Indo nesia yang terdapat di beberapa daerah seperti Sumatera, Jawa, dan Kalimantan. Ikan tengadak bernilai ekonomistinggi sebagai ikan konsumsi. Produksi ikan tengadak di Indonesia sampai saat ini sebagian besar masih berasal dari hasil tangkapan di alam. Upaya budidaya belum banyak dilakukan untuk melestarikan keberadaan jenis ikan ini, sehingga dikhawatirkan populasinya semakin berkurang dan mengalami kepunahan (Gustiano et al., 2015). Pengembangan 
budidaya ikan tengadak dapat dilakukan dari pengelolaan sumberdaya genetik populasi yang berkelanjutan dan berkualitas. Sumberdaya genetik tidak terlepas dengan ragam genetik.

Ragam genetik merupakan kunci penting bagi suatu spesies untuk dapat bertahan hidup dan menjamin kestabilan populasi dalam waktu yang lama, yaitu menentukan kemampuan respons suatu populasi terhadap seleksi alam. Populasi dengan keragaman genetik yang tinggi memiliki peluang hidup yang lebih tinggi, karena banyaknya alternatif gen dan kombinasi gen yang tersedia untuk merespons perubahan kondisi lingkungan yang dihadapi (Soewardi, 2007). Ragam genetik merupakan parameter kunci kebugaran populasi yang menjamin keberlanjutannya dan kemampuan merespons secara pasif seleksi alam ataupun buatan (Lorenzen et al., 2012). Identifikasi keragaman genetik dalam suatu populasi dapat dilakukan dengan pemetaan secara genotipe. Salah satu metode karakterisasi genotipe adalah analisis molekuler dengan metode Random Amplified Polymorphic DNA (RAPD) menggunakan teknik PCR (Polymerase Chain Reaction). Penanda molekuler RAPD yang digunakan merupakan sekuen DNA polimorfik yang dipisahkan oleh gel elektroforesis PCR. Metode RAPD memiliki beberapa keunggulan di antaranya mampu mendeteksi sekuen nukleotida hanya dengan satu primer dan dapat digunakan tanpa mengetahui latar belakang genom sebelumnya (Dunham, 2004). Marka RAPD ideal karena polimorfismenya tinggi (Liu, 2007). RAPD untuk menggambarkan keragaman genetik intra- dan inter-populasi ikan-ikan spesifik lokal yang sudah dilakukan meliputi: ikan kancra (Nugroho et al., 2006), ikan torsoro (Asih et al., 2008), ikan tawes (Kusmini et al., 2009), ikan nilem (Mulyasari, 2010), ikan tambakan (Sundari et al., 2012), ikan betok (Fayumi, 2013), ikan gabus (Gustiano et al., 2013), dan ikan sepat (Iskandariah et al., 2015).

Tujuan penelitian ini adalah untuk mengevaluasi keragaman genetik ikan tengadak asal Jawa, Kalimantan, dan progeni hibrid berdasarkan analisis RAPD untuk menyediakan database genetika sebagai acuan dalam pengembangan budidaya.

\section{BAHAN DAN METODE}

\section{Sampel Induk}

Ikan tengadak yang digunakan berasal dari Jawa (Balai Pelestarian Perikanan Perairan Umum, Dinas Kelautan dan Perikanan Provinsi Jawa Barat) dengan karakteristik lingkungan (suhu $24^{\circ} \mathrm{C}-30^{\circ} \mathrm{C}$; pH 5-7; dan oksigen terlarut 4-5,6 mg/L) dan Kalimantan (Balai Budidaya Ikan Sentral, Anjungan Kalimantan Barat) dengan karakteristik lingkungan (suhu $29^{\circ} \mathrm{C}-33^{\circ} \mathrm{C} ; \mathrm{pH}$
5-7,4; dan oksigen terlarut 4,5-6,6 mg/L). Ikan tengadak yang digunakan berukuran panjang 15,2 \pm $1,1 \mathrm{~cm}$ dan bobot $124,2 \pm 28,5 \mathrm{~g}$. Jumlah sampel yang digunakan untuk analisis RAPD sebanyak 15 ekor (delapan jantan dan tujuh betina) setiap populasi. Spesimen yang digunakan untuk analisis RAPD adalah sampel sirip yang disimpan dalam larutan alkohol $70 \%$

\section{Progeni Hibrida}

Ikan tengadak yang digunakan berupa larva hasil persilangan secara resiprokal berukuran $1-2 \mathrm{~cm}$ (berumur satu bulan pasca tetas). Jumlah sampel yang digunakan untuk analisis RAPD sebanyak 10 ekor setiap populasi. Spesimen yang digunakan untuk analisis RAPD adalah whole body yang disimpan dal am larutan al kohol $70 \%$

\section{RAPD (Random Amplified Polymorphic DNA)}

\section{Ekstraksi DNA}

Ekstraksi DNA ikan dilakukan dengan metode Phenol-Chloroform (Nugroho et al., 1997).

\section{Amplifikasi DNA dengan teknik PCR}

Amplifikasi DNA dilakukan dengan metode PCR dimulai dengan seleksi 25 primer. Pengujian primer dari OPA-01 sampai OPA-20, dan OPC-01 sampai OPC05 dengan komposisi bahan: $1 \mu \mathrm{L}$ DNA; 0,5 $\mu \mathrm{L}$ primer 10 pmol; satu unit (10 $\mu \mathrm{L})$ dry Taq Promega; dan distilled water $(8,5 \mu \mathrm{L})$ dengan total volume sebanyak $20 \mu \mathrm{L}$. Program PCR yang digunakan, meliputi: pre-denaturasi $94^{\circ} \mathrm{C}$ selama lima menit; denaturasi suhu $94^{\circ} \mathrm{C}$ selama satu menit; annealing suhu $36^{\circ} \mathrm{C}$ selama satu menit; elongasi suhu $72^{\circ} \mathrm{C}$ selama 2,5 menit; elongasi akhir $72^{\circ} \mathrm{C}$ selama tujuh menit; dan proses penstabilan $4^{\circ} \mathrm{C}$ selama tiga menit. Proses PCR berlangsung sebanyak 45 siklus. Hasil PCR memperlihatkan bahwa primer OPA-08, OPA-09, dan OPC-02 memberikan produk amplifikasi lebih banyak dibandingkan primer-primer yang lain. Hasil PCR kemudian dielektroforesis menggunakan gel agarose $2 \%$ dalam Tris-Boric-EDTA (TBE) buffer. Hasilnya diamati dengan UV illuminator dan didokumentasikan dengan kamera Polaroid.

\section{Analisis Ragam Genetik}

Tingkat keragaman genetik intrapopulasi dianalisis menggunakan program Toolsfor Population Genetic Analysis (TFPGA) mengacu pada Wright (1978) yang dimodifikasi dari Rogers (1972) dalam Miller (1997), sedangkan hubungan kekerabatan interpopulasi dianalisis berdasarkan jarak genetik dengan program UPGMA (Unweight Pair M ethods Arithmetic) dan disajikan dalam bentuk dendrogram. 


\section{HASIL DAN BAHASAN}

\section{Keragaman Genetik Ikan Tengadak}

Amplifikasi DNA yang menggunakan tiga primer (OPA-08, OPA-09, dan OPC-02) pada progeni hasil persilangan ikan tengadak asal Jawa dan Kalimantan secara resiprokal memperlihatkan DNA teramplifikasi pada setiap lokus dan bervariasi, masing-masing ditampilkan pada Gambar 1, 2, 3, dan 4.
Jumlah dan ukuran fragmen teramplifikasi disajikan pada Tabel 1. Keragaman profil RAPD menunjukkan jumlah fragmen pada populasi hasil persilangan betina Kalimantan x jantan Jawa berkisar 12-15 dengan ukuran fragmen DNA teramplifikasi berkisar 150-2.500 bp. Pada persilangan betina Jawa $\mathrm{x}$ jantan Kalimantan memiliki jumlah fragmen 14-16 dengan ukuran fragmen DNA teramplifikasi berkisar 180-3.000 bp.

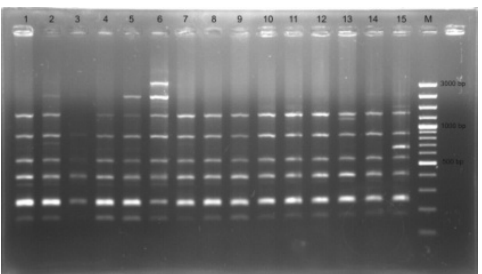

OPA 08

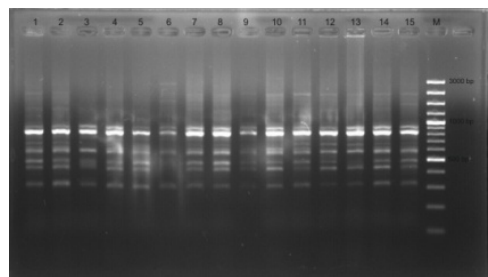

OPA 09

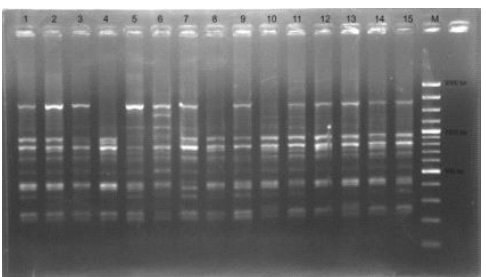

OPC 02

Gambar 1. Hasil amplifikasi DNA ikan tengadak asal Jawa dengan PCR-RAPD menggunakan primer OPA-08, OPA-09, dan OPC-02 (Keterangan: nomor (1-8)= sampel ikan jantan, (9-15)= sampel ikan betina, $\mathrm{M}=$ marker (GeneRuler $100 \mathrm{bp}$ Plus DNA Ladder, Thermo scientific)

Figure 1. DNA amplification results of tinfoil barb from Java with PCR-RAPD using OPA-08, OPA-09, and OPC-02 primers (Description: number (1-8)= male fish samples, $(9-15)=$ female fish samples, $M=$ marker (GeneRuler 100 bp Plus DNA Ladder, Thermo scientific)

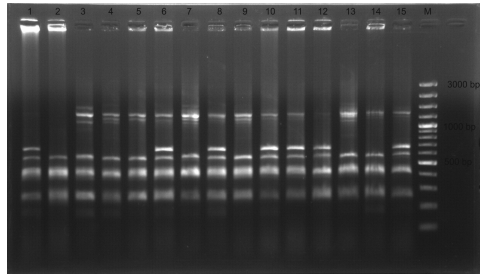

OPA 08

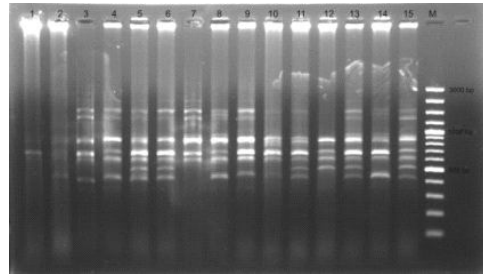

OPA 09

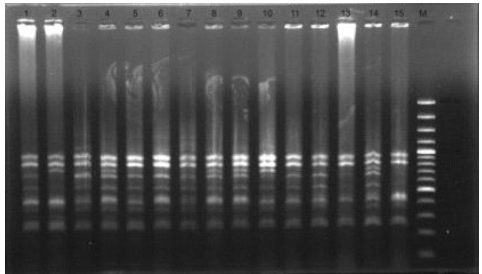

OPC 02

Gambar 2. Hasil amplifikasi DNA ikan tengadak asal Kalimantan dengan PCR-RAPD menggunakan primer OPA-08, OPA-09, dan OPC-02 (Keterangan: nomor (1-8)= sampel ikan jantan, $(9-15)=$ sampel ikan betina, $M=$ marker (GeneRuler 100 bp Plus DNA Ladder, Thermo scientific)

Figure 2. DNA amplification results of tinfoil barb from Kalimantan with PCR-RAPD using OPA-08, OPA-09, and OPC-02 primers (Description: number (1-8)= male fish samples, $(9-15)=$ female fish samples, $M=$ marker (GeneRuler 100 bp Plus DNA Ladder, Thermo scientific)

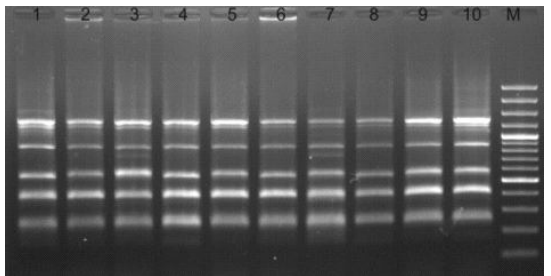

OPA 08

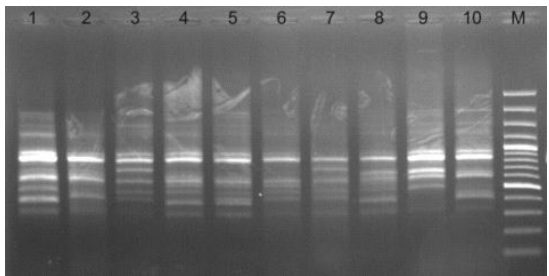

OPA 09

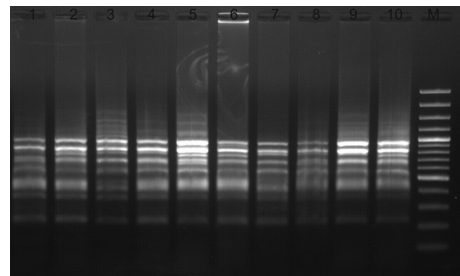

OPC 02

Gambar 3. Hasil amplifikasi DNA ikan tengadak hibrid (betina Jawa x jantan Kalimantan) dengan PCR-RAPD menggunakan primer OPA-08, OPA-09, dan OPC-02 (Keterangan: nomor (1-10)= sampel ikan, $M=$ marker (GeneRuler 100 bp Plus DNA Ladder, Thermo scientific)

Figure 3. DNA amplification results of tinfoil barb hybrid (female of Jawa $x$ male of Kalimantan) with PCR-RAPD using OPA-08, OPA-09, and OPC-02 primers (Description: number (1-10)= fish samples, $M=$ marker (GeneRuler 100 bp Plus DNA Ladder, Thermo scientific) 


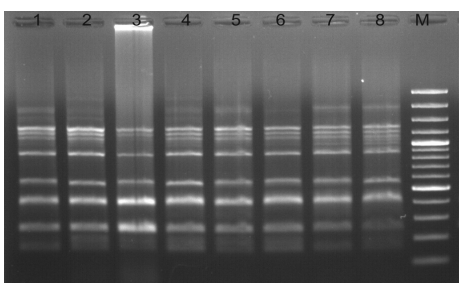

OPA 08

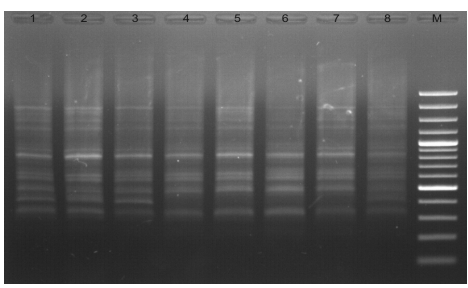

OPA 09

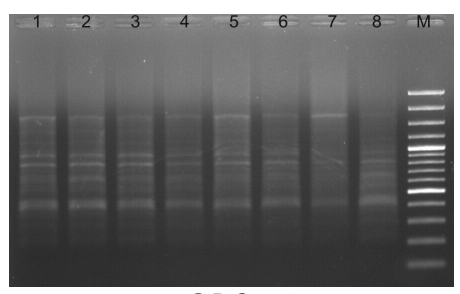

OPC 02

Gambar 4. Hasil amplifikasi DNA ikan tengadak hibrid (betina Kalimantan x jantan Jawa dengan PCR-RAPD menggunakan primer OPA-08, OPA-09, dan OPC-02 (Keterangan: nomor $(1-10)=$ sampel ikan, $M=$ marker (GeneRuler 100 bp Plus DNA Ladder, Thermo scientific)

Figure 4. DNA amplification results of tinfoil barb hybrid (female of Kalimantan $x$ male of Jawa) with PCR-RAPD using OPA-08, OPA-09, and OPC-02 primers (Description: number (1-10)= fish samples, $M=$ marker (GeneRuler 100 bp Plus DNA Ladder, Thermo scientific)

Tabel 1. Jumlah dan ukuran fragmen DNA produk PCR-RAPD menggunakan primer OPA-08, OPA-09, dan OPC 02 pada persilangan ikan tengadak asal Jawa dan Kalimantan secara resiprokal

Table 1. The number of fragments and size of DNA with PCR-RAPD using OPA-08, OPA-09, and OPC-02 primers resulting from reciprocal crossing of tinfoil barb from Java and Kalimantan

\begin{tabular}{lcc}
\hline \multicolumn{1}{c}{$\begin{array}{c}\text { Populasi } \\
\text { Populations }\end{array}$} & \multicolumn{2}{c}{ Amplifikasi (Amplification) } \\
\cline { 2 - 3 } & $\begin{array}{c}\text { Jumlah fragmen } \\
\text { Number of fragments }\end{array}$ & $\begin{array}{c}\text { Ukuran fragmen } \\
\text { Size of fragments }\end{array}$ \\
\hline $\begin{array}{l}\text { Betina Kalimantan x jantan Jawa } \\
\text { Female of Kalimantan x male of Java }\end{array}$ & $12-15$ & $150-2,500$ \\
Betina Jawa x jantan Kalimantan & $14-16$ & $180-3,000$ \\
Female of Java x male of Kalimantan & $11-15$ & $200-2,000$ \\
Jantan Kalimantan (Male of Kalimantan ) & $11-14$ & $200-2,000$ \\
Betina Kalimantan (Female of Kalimantan) & $12-16$ & $180-3,000$ \\
Jantan Jawa (Male of Java ) & $11-14$ & $180-2,000$ \\
Betina Jawa (Female of Java ) & & \\
\hline
\end{tabular}

Persentase polimorfisme dan heterozigositas secara lengkap disajikan pada Tabel 2. Persentase polimorfisme dan heterozigositas pada populasi hasil persilangan ikan tengadak memperlihatkan bahwa nilai polimorfisme tertinggi pada populasi betina Jawa $x$ jantan Kalimantan $(32,43 \%$ dan terendah pada populasi betina Kalimantan $\mathrm{x}$ jantan Jawa $(21,62 \%$. Tingkat heterozigositas yang tertinggi yaitu 0,13 pada populasi persilangan betina Jawa x jantan Kalimantan.

Perbedaan polimorfisme pita DNA yang dihasilkan tergantung pada situs penempelan primer dan dapat digunakan untuk memberikan gambaran mengenai tingkat keragaman genetik suatu populasi (Gusmiati et al., 2012; Gustiano et al., 2013). Populasi persilangan betina Jawa $x$ jantan Kalimantan memiliki nilai polimorfisme dan heterozigositas tertinggi $(32,43 \%$ dan 0,13 ) dibandingkan dengan persilangan betina Kalimantan $\mathrm{x}$ jantan Jawa yang hanya memiliki nilai sebesar $21,62 \%$ dan 0,10. Menurut Kusmini et al. (2011), tingginya tingkat polimorfisme pada populasi menunjukan efektivitas individu dalam proses seleksi (random mating) dan reproduksi di habitatnya.

Heterozigositas merupakan ukuran keragaman genetik berdasarkan proporsi jumlah individu heterozigot populasi (Soewardi, 2007). Semakin tinggi heterozigositas maka semakin banyak gen yang terlibat dalam menyumbangkan tingkat kebugaran suatu populasi (Tave, 1993). Secara statistik dengan menggunakan uji perbandingan berpasangan Fst (Tabel 3) menunjukkan perbedaan keragaman genetik 
Tabel 2. Persentase polimorfisme dan heterozigositas hasil persilangan ikan tengadak asal Jawa dan Kalimantan secara resiprokal

Table 2. Percentage of polymorphism and heterozigosity resulting from reciprocal crossing of tinfoil barb from Java and Kalimantan

\begin{tabular}{lcc}
\hline \multirow{1}{*}{$\begin{array}{c}\text { Populasi } \\
\text { Populations }\end{array}$} & \multicolumn{2}{c}{ Ragam genetik (Genetic diversity) } \\
\cline { 2 - 3 } & $\begin{array}{c}\text { Polimorfisme } \\
\text { Polymorphism (\%) }\end{array}$ & $\begin{array}{c}\text { Heterozigositas } \\
\text { Heterozigosity }\end{array}$ \\
\hline $\begin{array}{l}\text { Betina Kalimantan x jantan Jawa } \\
\text { Female of Kalimantan x male of Java }\end{array}$ & 21.62 & 0.10 \\
Betina Jawa x jantan Kalimantan & 32.43 & 0.13 \\
Female of Java x male of Kalimantan & 37.84 & 0.18 \\
Jantan Kalimantan (Male of Kalimantan) & 40.54 & 0.18 \\
Betina Kalimantan (Female of Kalimantan) & 37.84 & 0.15 \\
Jantan Jawa (Male of Java ) & 21.62 & 0.09 \\
Betina Jawa (Female of Java ) & &
\end{tabular}

yang nyata antar populasi persilangan $(P<0,05)$. Hasil uji Fst memberikan indikasi bahwa populasi yang ada belum tereksplorasi.

Berdasarkan analisis keragaman genetika intrapopulasi, jarak genetik masing-masing populasi (Tabel 4), diperoleh jarak genetik yang jauh dari hasil persilangan ikan tengadak $(0,4768)$. Untuk jarak genetik interpopulasi lebih lanjut disajikan pada Gambar 5. Populasi ikan tengadak hasil persilangan betina Jawa $x$ jantan Kalimantan menunjukkan hubungan kekerabatan yang lebih dekat dengan populasi induk Jawa, baik jantan maupun betina.
Berdasarkan dendrogram terlihat bahwa hubungan kekerabatan genetik populasi ikan tengadak hasil persilangan betina Jawa x jantan Kalimantan dan betina Kalimantan $\mathrm{x}$ jantan Jawa membentuk satu cluster. Kekerabatan ikan tengadak hasil persilangan cenderung lebih dekat atau lebih mirip dengan induk asal Jawa (jantan dan betina) dibandingkan dengan induk asal Kalimantan. Dendrogram merupakan hasil gabungan analisis dari tiga primer (OPA-08, OPA-09, dan OPC02) yang mengelompokkan populasi berdasarkan tingkat kemiripan genetik (Kusmini et al., 2015). Keragaman genetik merupakan parameter kunci

Tabel 3. Uji perbandingan berpasangan Fst pada ikan tengadak hasil persilangan secara resiprokal

Table 3. Pairwise comparison Fst resulting from reciprocal crossing of tinfoil barb

\begin{tabular}{|c|c|c|c|c|c|c|c|}
\hline \multirow{2}{*}{\multicolumn{2}{|c|}{$\begin{array}{l}\text { Populasi } \\
\text { Populations }\end{array}$}} & \multicolumn{2}{|c|}{ Jawa (Java ) } & \multicolumn{2}{|c|}{ Kalimantan } & \multicolumn{2}{|c|}{$\begin{array}{l}\text { Silang luar } \\
\text { Outbreed }\end{array}$} \\
\hline & & $\hat{\jmath}$ & q & $\hat{\sigma}$ & q & JK & $\mathbf{K J}$ \\
\hline \multirow{2}{*}{ Jawa (Java ) } & $\hat{0}$ & watk1k & & & & & \\
\hline & q & 1.0000 & *wetw & & & & \\
\hline \multirow{2}{*}{ Kalimantan } & $\hat{0}$ & 0.0000 & 0.0000 & 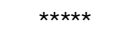 & & & \\
\hline & q & 0.0000 & 0.0000 & 10,000 & 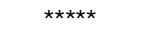 & & \\
\hline \multirow{2}{*}{$\begin{array}{l}\text { Silang luar } \\
\text { Outbreed }\end{array}$} & JK & 0.0000 & 0.0001 & 0.0000 & 0.0000 & **tw & \\
\hline & $\mathrm{KJ}$ & 0.0000 & 0.0000 & 0.0000 & 0.0000 & 0.0000 & * *1tw \\
\hline Keterangan: & \multicolumn{7}{|c|}{$\begin{array}{l}\text { Populasi betina }(\mathrm{f}) \text {, populasi jantan }(\mathrm{m}, \mathrm{KJ}=\text { Kalimantan } \mathrm{x} J a w a, \mathrm{~J}=\text { Jawa } \\
\left.\mathrm{x} \text { Kalimantan, populasi awal= betina, populasi akhir= jantan }{ }^{*}\right) \text { berbeda nyata } \\
(\mathrm{P}<0,05)\end{array}$} \\
\hline Description: & \multicolumn{7}{|c|}{$\begin{array}{l}\text { The female population }(f) \text {, the male population }(\mathrm{m}), \mathrm{KJ}=\text { Kalimantan } \mathrm{x} \\
\text { Java, JK= Java } x \text { Kalimantan, initial population }=\text { female, final population= } \\
\text { male }{ }^{*} \text { significantly different }(P<0.05)\end{array}$} \\
\hline
\end{tabular}


Tabel 4. Jarak genetik ikan tengadak hasil persilangan asal Jawa dan Kalimantan secara resiprokal

Table 4. Genetic distance resulting from reciprocal crossing of tinfoil barb from Java and Kalimantan

\begin{tabular}{|c|c|c|c|c|c|c|c|}
\hline \multirow{2}{*}{$\begin{array}{c}\text { Populasi } \\
\text { Populations }\end{array}$} & & \multicolumn{2}{|c|}{$\begin{array}{l}\text { Jawa } \\
\text { Java }\end{array}$} & \multicolumn{2}{|c|}{ Kalimantan } & \multicolumn{2}{|c|}{$\begin{array}{l}\text { Silang luar } \\
\text { Outcrossing }\end{array}$} \\
\hline & & $0^{\pi}$ & q & $\hat{0}$ & q & JK & $\mathrm{KJ}$ \\
\hline $\begin{array}{l}\text { Jawa } \\
\text { Java }\end{array}$ & $\begin{array}{l}\lambda \\
+\end{array}$ & 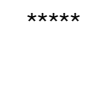 &  & & & & \\
\hline Kalimantan & $\begin{array}{l}\hat{0} \\
\text { + } \\
\end{array}$ & $\begin{array}{l}0.522 \\
0.505 \\
\end{array}$ & $\begin{array}{l}0.525 \\
0.516 \\
\end{array}$ & $\begin{array}{l}* \text { *小atw } \\
0.204 \\
\end{array}$ & *⿻一从火火从4k & & \\
\hline $\begin{array}{l}\text { Silang luar } \\
\text { Outcrossing }\end{array}$ & $\begin{array}{l}\mathrm{JK} \\
\mathrm{KI}\end{array}$ & $\begin{array}{l}0.437 \\
0.479\end{array}$ & $\begin{array}{l}0.432 \\
0.468\end{array}$ & $\begin{array}{l}0.461 \\
0.552\end{array}$ & $\begin{array}{l}0.468 \\
0.546\end{array}$ & $\begin{array}{l}* 4+14 \\
0.477\end{array}$ & *⿻丷木火火木 \\
\hline
\end{tabular}

Keterangan: $\quad$ Populasi betina ( $\mathrm{f}$ ), populasi jantan $(\mathrm{m}), \mathrm{KJ}=$ Kalimantan $\mathrm{x}$ Jawa, JK= Jawa $x$ Kalimantan, populasi awal = betina, populasi akhir = Jantan

Description: The female population ( $\mathrm{f}$ ), the male population $(\mathrm{m}), \mathrm{KJ}=$ Kalimantan $\mathrm{x}$ Java, $J K=$ Java $\times$ Kalimantan, initial population $=$ female, final population $=$ male
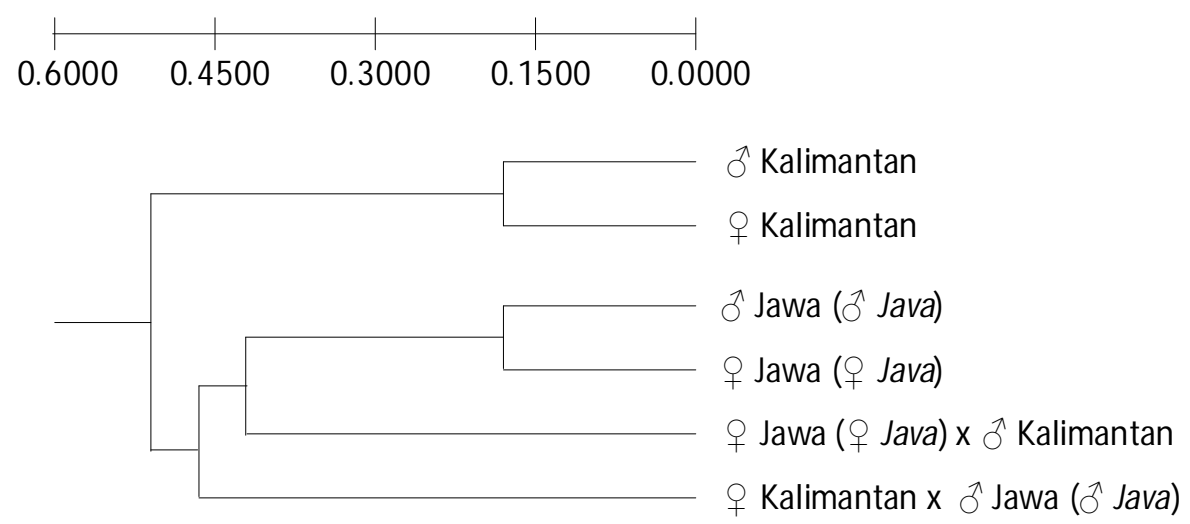

Gambar 5. Dendrogram hubungan kekerabatan ikan tengadak hasil persilangan berdasarkan keragaman OPA-08, OPA-09, dan OPC-02

Figure 5. Genetic relationship dendrogram between crossbred results based on OPA08, OPA-09, and OPC-02 diversity

kebugaran populasi yang menjamin keberlanjutannya dan kemampuan merespons secara pasif seleksi alam ataupun buatan (Lorenzen et al., 2012). Perbedaan keragaman genetik dapat meningkatkan jarak genetik antar populasi dan umumnya digunakan sebagai pertimbangan dalam melakukan seleksi dan persilangan. Secara umum, rendahnya keragaman genetik intrapopulasi akan mengakibatkan munculnya sifat negatif antara lain pertumbuhan lambat, reproduksi dan tingkat adaptasi yang rendah (Leary et al., 1985).

\section{KESIMPULAN}

Keragaman genetik ikan tengadak hasil persilangan betina Jawa $x$ jantan Kalimantan menunjukkan polimorfisme dan heterozigositas tertinggi $(32,43 \%$ dan 0,13 ). Analisis keragaman genetika interpopulasi hasil persilangan ikan tengadak asal Jawa dan Kalimantan diperoleh jarak genetik yang jauh $(0,48)$. Ikan tengadak betina asal Jawa dan jantan asal Kalimantan berpotensi sebagai sumber genetik donor untuk pengembangan budidaya ikan tengadak yang berkelanjutan. 


\section{UCAPAN TERIMA KASIH}

Ucapan terima kasih disampaikan kepada Balai Penelitian dan Pengembangan Budidaya Air Tawar, Bogor karena sudah mendanai kegiatan ini melalui APBN 2015. Terima kasih juga kepada Saudara Sudarmaji dan Fera Permata Putri atas bantuan yang diberikan selama penelitian.

\section{DAFTAR ACUAN}

Asih, S., Nugroho, E., Kristanto, A.H., \& Mulyasari. (2008). Penentuan variasi genetik ikan batak (Tor soro) dari Sumatera Utara dan Jawa Barat dengan metode analisis Random Amplified Polymorphism DNA (RAPD). J. Ris. Akuakultur, 3(1): 91-97.

Dunham, R.A. (2004). Aquaculture and fisheries biotechnology: Genetic approach. CABI Publishing. Cambridge USA, p. 85-99.

Fayumi, U. (2013). Karakterisasi fenotipe morfometrik dan genotipe RAPD (Random Amplified Polymorphic DNA) ikan betok (Anabas testudineus Bloch, 1792). Skripsi. Institut Pertanian Bogor.

Gusmiati, Restu, M., \& Pongtuluran. (2012). Seleksi primer untuk analisa keragaman genetik jenis bitti (Vites coffassus). Jurnal Perennial, 8, 25-29.

Gustiano, R., Kusmini, I., \& Ath-thar, M.F.H. (2015). Mengenal sumber daya genetik ikan spesifik lokal air tawar Indonesia untuk pengembangan budidaya. IPB Press. Bogor, hlm. 1-51.

Gustiano, R., Oktaviani, T., Soelistyowati, D.T., Kusmini, I., Wahyutomo, \& Huwoyon, G.H. (2013). Analisa ragam genotipe RAPD dan fenotipe truss morphometric pada tiga populasi ikan gabus (Channa striata). Berita Biologi, 12(3), 325-333.

Iskandariah, Soelistyowati, D.T., Gustiano, R., Kusmini, I.I., \& Huwoyon, G.H. (2015). Ragam genetik tiga populasi sepat siam asal Kalimantan menggunakan analisis RAPD dan pengukuran morfometrik truss. Berita Biologi, 14(1), 57-68.

Kusmini, I.I., Gustiano, R., \& Mulyasari. (2011). Karakterisasi genetik ikan Kelabau (Osteochilus kelabau) dari berbagai lokasi di Kalimantan Barat menggunakan analisis RAPD. Berita Biologi, 10(4), 449-454.

Kusmini, I.I., Mulyasari,Widiyati, A., \& Nugroho, E. (2009). Karakter genetik ikan tengadak (Barbodes sp.), ikan tawes albino (Barbodes sp.) dan ikan tawes (Barbodes gonionotus). Prosiding Seminar Nasional Tahunan VI Hasil Penelitian Perikanan dan Kelautan. Universitas Gadjah Mada. Yogyakarta, hlm. 332338.
Kusmini, I.I., Prakoso, V.A., \& Kusdiarti. (2015). Keragaman fenotipe truss morfometrik dan genotipe ikan gabus (Channa striata) dari Jawa Barat, Sumatera Selatan dan Kalimantan Tengah. J. Ris. Akuakultur, 10(4), 501-509.

Leary, R.F., Allendrof, F.W., \& Knudsen, K.L. (1985). Development instability and high meristic counts in interspecific hybrid of salmonid fishes. Evolution, 39, 318-326.

Liu, Z.J. (2007). Randomly amplified polymorphism DNA (RAPD). In Aquaculture genome technologies. Liu, Z.J. (Ed.). Blackwell Publishing. USA, . 21-28.

Lorenzen, K., Beveridge, M.C.M., \& Mangel, M. (2012). Cultured fish: integrative biology and management of domestication and interactions with wild fish. Biology Review, 87, 639-660.

Miller, M.P. (1997). Tools for population genetic analysis (TFPGA) version 1.3. Department of Biological Science. Northern Arizona University, Arizona, USA.

Mulyasari. (2010). Karakteristik fenotipe morfomeristik dan keragaman genotipe RAPD (Random Amplified Polymorphism DNA) ikan nilem (Osteochilus hasselti) di Jawa Barat. Tesis. Institut Pertanian Bogor.

Nugroho, E., Takagi, M., \& Taniguchi, N. (1997). Practical manual on detection of DNA polymorphism in fish population study. Buletin of Marine Sciences and Fisheries. Kochi University. Japan, 17, 109-129.

Nugroho, E., Subagja, J., Asih, S., \& Kurniasih, T. (2006). Evaluasi keragaman genetik ikan kancra dengan menggunakan marker mt DNA D-loop dan Random Amplified Polymorphism DNA (RAPD). J. Ris. Akuakultur, 1(2), 211-217.

Soewardi, K. (2007). Pengelolaan keragaman genetik sumber daya perikanan dan kelautan. Departemen Manajemen Sumberdaya Perairan. Institut Pertanian Bogor. Bogor. $153 \mathrm{hlm}$.

Sundari, S., Iskandariah, Huwoyon, G.H., Kusmini, I.I., \& Gustiano, R. (2012). Keragaman genetik tiga populasi ikan tambakan (Helostoma temminckii) asal Sumatera, Jawa, dan Kalimantan menggunakan metode RAPD. Prosiding Forum Inovasi Teknologi Akuakultur. Pusat Penelitian dan Pengembangan Perikanan Budidaya. Jakarta, hlm. 1109-1114.

Tave, D. (1993). Genetic for fish hatchery managers. Kluwer Acad Publ. Netherland, 415 pp. 